\title{
Developing Methods to Assess and Monitor Cluster Structures: The Case of Digital Clusters
}

\author{
Tatiana Kudryavtseva ${ }^{1 *}$, Natalia Kulagina ${ }^{2}$, Alexandra Lysenko² ${ }^{2}$ Mohammed Ali Berawi ${ }^{3}$, \\ Angi Skhvediani ${ }^{1}$ \\ ${ }_{1}^{1}$ Peter the Great St. Petersburg Polytechnic University, Saint Petersburg 195251, Russia \\ ${ }^{2}$ Bryansk State University of Engineering and Technology, Bryansk 241035, Russia \\ ${ }^{3}$ Department of Civil Engineering, Faculty of Engineering, Universitas Indonesia, Kampus UI Depok, Depok \\ 16424, Indonesia
}

\begin{abstract}
The purpose of this work is to develop a methodology to assess and monitor cluster structures. The authors' proposed method assesses the level of cluster structure development by considering cluster transformation analysis in the information and communication sectors of the regional economy, prerequisites for cluster formation, and the current level of digital cluster development in the region. To evaluate the prerequisites of digital economy cluster formation, an integral indicator is calculated and a multi-parameter approach is used to evaluate cluster effectiveness. The integral indicator includes 17 values calculated using the scorecard evaluation method. To make conclusions about the stages of IT cluster development, the authors provide the scale used to interpret integral indicator values. This scale classifies cluster development using four levels: beginner, elementary, intermediate, and advanced. A comparative analysis of IT cluster development in the Kaluga and Bryansk regions of the Russia reveals that IT clusters in Kaluga are at an advanced level of development due to its highly developed infrastructure and work flow organization, while IT clusters in Bryansk are at the beginner stage. This shows that Kaluga has a more effective industrial policy for clusters. The proposed methodology allows researchers to compare clusters from different regions and monitor their development.
\end{abstract}

Keywords: $\quad$ Cluster; Innovation; IT cluster; Regional innovation system; Russia

\section{Introduction}

The development of cluster structures boosts regional and national economic processes, which has a positive effect on the investment attractiveness and socio-economic potential of the region and leads to the creation of new enterprises and jobs (Rudskaya and Rodionov, 2017; Isaksen, 2018; Lehmann and Menter, 2018; Schepinin et al., 2018).

In the $20^{\text {th }}$ century, clusters began to be considered the most important factor in regional development (Gutman et al., 2017; Kozonogova et al., 2019). Regions with developed cluster structures are more competitive; clusters are a foothold for successful regional economies. The aggregation of enterprises and organizations into cluster makes it possible to increase their effectiveness (Kudryavtseva et al., 2020). In addition, clusterisation can provide higher localization economies from land and infrastructure usage (Berawi, 2018; Berawi et al., 2019).

*Corresponding author's email: aeskhvediani@mail.ru or shvediani_ae@spbstu.ru, Tel.: +7 (812) 534-73-31 doi: 10.14716/ijtech.v11i4.4191 
In accordance with the Russian Federation's two main development programs-Digital Economy of the Russian Federation (Government of the Russian Federation, 2017) and Economic Development and Innovative Economy (Government of the Russian Federation, 2014) - clusters (digital clusters in particular) should become one of the main forms of economic activity to ensure economic growth. Therefore, it is essential to analyze existing approaches to cluster development evaluation and test them using a Russian digital cluster.

The paper aims to develop a method for assessing and monitoring cluster effectiveness. To do this, it is necessary to complete the following tasks:

- consider the existing definitions of "cluster" in the works of Russian and international researchers;

- study scientific approaches used to assess the effectiveness of cluster structures; and

- propose a method for assessing the effectiveness of cluster structures that considers cluster development analysis in the information and communication sectors of the region's economy, prerequisites for cluster formation, and the current level of digital cluster development in the region.

The "Literature review" section discusses various definitions of the term "cluster" present in Russian and international scientific works, as well as existing approaches for assessing cluster effectiveness. The "Data and method" section describes the method for evaluating the effectiveness of digital clusters, taking into account the analysis of prerequisites for cluster formation and the current level of digital development in the regions. The "Results and discussion" section discusses the test results for the authors' method of assessing the effectiveness of digital economy clusters in the Bryansk region. The main findings of the work are summarized in the "Conclusions" section.

\section{Literature Review}

\subsection{Analysis of Various Definitions of the Term "Cluster" in the Scientific Literature}

The term "cluster" became popular in the late 1980s and is currently used to refer to one of the tools in effective regional development. Today, clusters are studied by scientists around the world.

During the $20^{\text {th }}$ century, a lot of research, within the theoretical frameworks for economic growth and development, focused on ways of optimizing the locations of enterprises and industries in terms of transport and resource constraints. Marshall (1890) was the first to address this topic; he studied the formation of groups comprising industrial enterprises in certain geographic locations, which led to an increase in labor productivity and economic development. Relying on this work and its extensions, today's researchers delve into the economy of agglomeration or co-location to assess the efficiency of cluster structures (Zhu et al., 2017; Fracasso and Vittucci Marzetti, 2018). On the other hand, research dedicated to the exploration and assessment of the economy in view of competition and diversification found more evidence of their positive influence on regional economy (Caragliu et al., 2016).

According to Porter (1998), clusters are groups of industrial enterprises whose activities are based on highly developed production technologies. In his definition, he included small businesses whose activities contributed to the main enterprises' functions. Porter also believed that countries that concentrate industrial enterprises in certain geographic locations are characterized by increased levels of competitiveness created by enterprise cooperation, highly qualified personnel, and innovative development.

Sustainable cluster development is widely discussed in the scientific literature; it focuses on the idea that clusters can be central to not only a region's economy, but also its 
sociology, ecology, and innovation spheres (Chen et al., 2020a; Moeis et al., 2020). For example, some studies only estimate the cluster's economic performance and make conclusions that focus on its efficiency (Putri et al., 2016). Others analyze the relationship between social capital and cluster performance (Steinfield et al., 2010). Further, some studies prove how clusters affect total factor ecological performance (Chen et al., 2020b). Many researchers have paid contributed to the study of innovative clusters, defining the research sector's large role in cluster development (Boekholt and Thuriaux, 1999; Wiratmadja et al., 2016).

Recently, there has been increased attention on the study of clusters at the regional level in the Russian Federation. Authorities plan to realize regional competitive potential.

Following the guidelines for implementing the cluster policy in Russia's constituent entities, the cluster can be located in the territory of one or several regions. The guidelines define the cluster as a set of enterprises and their suppliers, catering services, and research organizations associated with the production of certain goods and services (Ministry of Economic Development, 2008). Kleiner et al. (2008) noted that clusters should include not only enterprises, but also elements of infrastructure, universities, and research institutes. All constituent elements of the cluster should be connected by territorial relations and closely cooperate during the production processes and the sale of products (Kleiner et al., 2008). Pososhkov (2017) considered the geographical location of enterprises as well as their industrial affiliation and use of innovative technologies. The competition between cluster enterprises contributes to increasing the competitiveness of the entire cluster (Pososhkov, 2017). Beloglazova (2019) defined clusters as a form of interaction between enterprises, with a system of transactional relations in the production process and sale of innovative products. Thus, the authors considered approaches that were quite similar in terms of the geographical location of cluster enterprises; the integration of production processes, resources, capital, and other competitive advantages; the relationships between enterprises; and the favorable outcomes for the region's economy.

Therefore, the conducted analysis revealed that cluster formation makes it possible to solve many regional and local problems and to implement projects at the regional level by using the capacities of one industry to develop others (Delgado et al., 2015; Taglioni and Winkler, 2016; Litzel, 2017; Kudryavtseva et al., 2018; Selentyeva et al., 2018).

\subsection{Existing Approaches to Assessing Cluster Effectiveness}

Assessment of cluster effectiveness is quite relevant and is discussed in some scientific works. In specific, there are several Russian works that present models to evaluate cluster effectiveness. Tsertseil and Kokuyeva (2018) presented an approach to assess the total value of benefits for enterprises in a cluster. This approach was based on a system of relative indicators that highlighted socio-economic processes that affected the cluster and its participants. Four groups of assessment criteria were determined, and the total value of benefits for enterprises in a cluster was calculated using the following equation:

$$
B C=f(P S, P F, I P)
$$

where $B C$ is the total value of benefits for enterprises in a cluster, $P S$ is the product structure output of production cluster participants, $P F$ is the availability of production factors to cluster participants, and $I P$ is the intellectual (innovation) potential of the production cluster.

Moreover, Kovaleva (2018) proposed the use of the Regional Cluster Index, a collection of 39 indicators including institutional, economic, innovative and cluster effectiveness measures. 
Some papers take a multi-parameter approach. For example, Ibragimova and Tokunov (2016) proposed an assessment that considered 11 areas. Each area has several relevant industry-specific indicators, such as product evaluation and the assessment of cluster members, infrastructure security, financial and innovative components, investments and staff performance appraisal from the position of the state (Ibragimova and Tokunov, 2016).

International research also proposes some interesting approaches for assessing cluster effectiveness. For example, Maggioni (2004) used an approach that focused on calculating the net positive effect in the cluster. The approach represented a cluster's developmental trends in connection with the district's life cycle using the position of the cluster in the region, which affects costs and benefits. As a result, the net positive effect on the cluster's territory is calculated as a function of costs and benefits. This indicator depends on the geographical location, capital, labor, suppliers, quality of the infrastructure, and advantages of agglomerating enterprises.

Moreover, Strøjer Madsen et al. (2003) proposes a model to assess the influence of a cluster's competitive advantages using its performance. The resulting indicator depends on the performance of factors within a certain period, the enterprise's affiliation with a specific industry or district, the volume of labor costs, and the total capital.

Further, it is essential to estimate the cluster's influence on regional development indicators. For example, Humphrey and Schmitz (2002) presented a value chain calculation that assessed individual factors, including the cluster's influence on regional development, the concentration of human resources, wages, and the poverty indicator in the region.

Therefore, models proposed by foreign authors used the same components to indicate main influence factors. Models proposed by Russian scientists were mainly based on calculations and multi-parameter approaches. A large number of indicators were used to create a comprehensive assessment of the cluster's impact on the socio-economic development of the region.

Many different methods for assessing cluster effectiveness can be applied to production clusters in various sectors of the economy, which limits their application to digital clusters due to their specifics. It is necessary to develop a method for evaluating digital cluster effectiveness that considers not only its distinctive features, but also the prerequisites and conditions of its regional function as well as its effectiveness. Classifying digital clusters using their level of development makes it possible to assess which districts need stimulation for activities in the field of digitalization. This will allow the entire region to reach a new level of digital development.

\section{Data and Method}

Cluster development in the digital economy has specific features due to the need to modernize Information and communications technology (ICT) infrastructure, which implies developing home software, training highly skilled personnel, and more (Kudryavtseva et al., 2018; Kuporov et al., 2018; Kozonogova et al., 2019). At the same time, the scientific and technological development in some regions indicates their readiness for digital transformation (Andreyeva et al., 2018; Schepinin et al., 2018; Rodionov and Rudskaia, 2019).

In the context of active digitalization, clusters in the ICT sector have a direct impact on the socio-economic indicators of regional development by increasing the regions' budget , improving the standard of living, creating a positive image of the region, ensuring competitiveness. In this respect, it is necessary to evaluate the effectiveness of cluster structures, which is hampered by the lack of official statistics on some important indicators characterizing, for example, cluster size and specialization as well as financial and 
investment opportunities.

Using literature that focuses on developing assessments to determine cluster effectiveness, the authors attempted to systematize indicators $(P)$ characterizing the level of cluster development in the ICT sector of the region based on a multi-parameter approach.

$P_{1-5}$ and $P_{15}$ represent cluster competitiveness; this was presented in the Methodological recommendations on realization of cluster policy in the Russian Federation (Ministry of Economic Development, 2008). $P_{6-10}$ and $P_{17}$ are taken from analytical research performed by the Higher School of Economics in Russia (Abashkin et al., 2018). The authors define $P_{11-14}$ using the aims and objectives of the cluster industrial policy at the regional level.

Each of the proposed factors is rated using a five-point scale (1 - minimum low value; 2 - low value; 3 - average value; 4 - good value; 5 - maximum value). The minimum and maximum number of points that can be obtained are 17 and 85, respectively. The weight coefficient for each resulting aggregated factor $\left(\alpha_{1}-\alpha_{n}\right)$ depends on its influence on the level of cluster development in economy digitalization. The authors determined the weight coefficients by administering a survey method to key decision-makers and scientists in the Bryansk region. They were asked to distribute 100 points among 17 indicators; the number of points assigned to each indicator determined its importance. The average score for each indicator was then divided by 100 to obtain the proportion (i.e., its relevant importance [weight]). Table 1 shows the indicators used to assess the level of cluster structure development in the ICT sector of the region.

Table 1 Indicators for assessing the level of cluster structure development in the ICT sector of the region

\begin{tabular}{|c|c|c|}
\hline $\begin{array}{l}\text { Digital cluster development indicators } \\
\qquad(P)\end{array}$ & $\begin{array}{l}\text { Weight coefficient } \\
\qquad(\alpha)\end{array}$ & $\begin{array}{c}\text { Expert } \\
\text { assessment }\end{array}$ \\
\hline $\begin{array}{l}\text { The total amount of work and services performed by members of the } \\
\text { digital economy cluster }\left(P_{1}\right)\end{array}$ & 0.06 & $1-5$ \\
\hline The level of export of products, works, and services $\left(P_{2}\right)$ & 0.06 & $1-5$ \\
\hline The level of product sales, works, services outside the region $\left(P_{3}\right)$ & 0.07 & $1-5$ \\
\hline The value added by digital economy cluster members $\left(P_{4}\right)$ & 0.06 & $1-5$ \\
\hline The annual increase in the number of cluster members $\left(P_{5}\right)$ & 0.05 & $1-5$ \\
\hline The total number of jobs at the digital economy cluster $\left(P_{6}\right)$ & 0.06 & $1-5$ \\
\hline $\begin{array}{l}\text { The total number of high-performance jobs at member enterprises in the } \\
\text { digital economy cluster }\left(P_{7}\right)\end{array}$ & 0.11 & $1-5$ \\
\hline $\begin{array}{l}\text { The proportion of cluster members in the total number of people } \\
\text { employed in this industry, } \%\left(P_{8}\right)\end{array}$ & 0.05 & $1-5$ \\
\hline The staff level, $\%\left(P_{9}\right)$ & 0.08 & $1-5$ \\
\hline $\begin{array}{l}\text { The number of small- and medium-sized member enterprises in the } \\
\text { digital economy cluster, units }\left(P_{10}\right)\end{array}$ & 0.04 & $1-5$ \\
\hline The number of projects in the field of digital transformation, units $\left(P_{11}\right)$ & 0.05 & $1-5$ \\
\hline $\begin{array}{l}\text { The proportion of research and educational institutions in the total } \\
\text { number of cluster members, } \%\left(P_{12}\right)\end{array}$ & 0.03 & $1-5$ \\
\hline $\begin{array}{l}\text { The resources available for infrastructure, production, and innovation, as } \\
\text { well as the infrastructure available to support the development of small- } \\
\text { and medium-sized enterprises in the cluster }\left(P_{13}\right)\end{array}$ & 0.09 & $1-5$ \\
\hline $\begin{array}{l}\text { Centers for digital transformation, partnership interactions, development } \\
\text { of digital technologies }\left(P_{14}\right)\end{array}$ & 0.04 & $1-5$ \\
\hline $\begin{array}{l}\text { The share of cluster products (e.g., works and services) in the regional } \\
\text { market }\left(P_{15}\right)\end{array}$ & 0.05 & $1-5$ \\
\hline The number of completed projects over the past five years $\left(P_{16}\right)$ & 0.03 & $1-5$ \\
\hline Return on investment, $\%\left(P_{17}\right)$ & 0.07 & $1-5$ \\
\hline$\sum \mathrm{P}$ & 1 & $17-85$ \\
\hline
\end{tabular}


The integral indicator $\left(I_{c}\right)$ characterizes the level of cluster structure development in the information and communication sectors of the region. It can be determined using the following score assessment method:

$$
\boldsymbol{I}_{\boldsymbol{c}}=P_{1} \alpha_{1}+P_{2} \alpha_{2}+P_{3} \alpha_{3}+\ldots P_{n} \alpha_{n} .
$$

The integral indicator can then be classified using Table 2 , which assigns $I_{c}$ values to stages of cluster development.

Table 2 Scale to define the stage of cluster development assessment

\begin{tabular}{cc}
\hline$I_{c}$ value & Stages of cluster development \\
\hline $1-2$ & Beginner \\
$2-3$ & Elementary \\
$3-4$ & Intermediate \\
$4-5$ & Advanced \\
\hline
\end{tabular}

Based on the results obtained, it is possible to assess clusters in terms of innovative activities in the field of digital products and to evaluate the prospects for achieving the main strategic goal of the cluster.

\section{Results and Discussion}

The methodological approach was applied to two regions in Russia: Bryansk and Kaluga. Comparative results of the expert assessment are presented in Table 3.

Table 3 Comparative analysis of IT cluster development stages in Bryansk and Kaluga, Russia

\begin{tabular}{|c|c|c|c|c|c|}
\hline \multirow{2}{*}{$\begin{array}{c}\text { Digital cluster } \\
\text { development indicators } \\
(P)\end{array}$} & \multirow{2}{*}{$\begin{array}{l}\text { Weight coefficient } \\
\qquad(\alpha)\end{array}$} & \multicolumn{2}{|l|}{ Bryansk } & \multicolumn{2}{|l|}{ Kaluga } \\
\hline & & $\begin{array}{l}\text { Average expert } \\
\text { assessment }(P)\end{array}$ & $\alpha^{*} P$ & $\begin{array}{l}\text { Average expert } \\
\text { assessment }(P)\end{array}$ & $\alpha^{*} P$ \\
\hline$P_{1}$ & 0.06 & 1.7 & 0.10 & 4.78 & 0.29 \\
\hline$P_{2}$ & 0.06 & 1.0 & 0.06 & 3.89 & 0.23 \\
\hline$P_{3}$ & 0.07 & 1.7 & 0.12 & 4.44 & 0.31 \\
\hline$P_{4}$ & 0.06 & 1.7 & 0.10 & 4.00 & 0.24 \\
\hline$P_{5}$ & 0.05 & 1.3 & 0.07 & 3.89 & 0.19 \\
\hline$P_{6}$ & 0.06 & 1.3 & 0.08 & 4.67 & 0.28 \\
\hline$P_{7}$ & 0.11 & 1.2 & 0.13 & 3.89 & 0.43 \\
\hline$P_{8}$ & 0.05 & 1.1 & 0.06 & 4.78 & 0.24 \\
\hline$P_{9}$ & 0.08 & 1.7 & 0.13 & 4.44 & 0.36 \\
\hline$P_{10}$ & 0.04 & 1.1 & 0.04 & 4.33 & 0.17 \\
\hline$P_{11}$ & 0.05 & 2.1 & 0.11 & 4.78 & 0.24 \\
\hline$P_{12}$ & 0.03 & 1.1 & 0.03 & 4.89 & 0.15 \\
\hline$P_{13}$ & 0.09 & 1.4 & 0.13 & 5.00 & 0.45 \\
\hline$P_{14}$ & 0.04 & 1.4 & 0.06 & 4.56 & 0.18 \\
\hline$P_{15}$ & 0.05 & 1.4 & 0.07 & 4.78 & 0.24 \\
\hline$P_{16}$ & 0.03 & 1.2 & 0.04 & 4.78 & 0.14 \\
\hline$P_{17}$ & 0.07 & 1.1 & 0.08 & 4.89 & 0.34 \\
\hline$I_{c}$ & $\mathrm{~N} / \mathrm{A}$ & $\mathrm{N} / \mathrm{A}$ & 1.40 & $\mathrm{~N} / \mathrm{A}$ & 4.48 \\
\hline \multicolumn{2}{|c|}{ Stage of cluster development } & \multicolumn{2}{|l|}{ Beginner } & \multicolumn{2}{|c|}{ Advanced } \\
\hline
\end{tabular}

The integral indicator for Bryansk is 1.40, which concludes that its IT cluster development is at the beginner stage. However, for Kaluga, the integral indicator is 4.48, indicative of an advanced level of development. Kaluga's high level of IT cluster development is due to several reasons. First, regional education centers provide the cluster 
with highly qualified personnel. Second, this cluster has organized export-oriented competitive production. Third, Kaluga has provided necessary infrastructure for IT cluster development. The region has been involved in regional activities that have boosted the competitiveness of IT cluster enterprises.

The proposed approach allows regions to be ranked by their stage of cluster development using information delivered from the government, scientific, and business communities to the experts. This approach is more universal than the methods discussed in the literature review (Ibragimova and Tokunov, 2016; Kovaleva, 2018). In particular, their results do not allow clusters to be compared and require precise information, which is not always available to the researcher. In addition, some methodologies do not specify the weights of indicators or classify obtained results. The advantage of this research is the simplicity of the calculations and their universality, meaning that proposed approach can be used for assessment of any cluster. The integral indicator value and its dynamics allow researchers to make conclusions about changes in infrastructure development, achievement of cluster development aims and goals, and managerial decisions, which should be taken into consideration to enhance cluster development.

\section{Conclusions}

While the study revealed that there are many definitions of the term "cluster", approaches in the literature highlighted the same cluster characteristics: geographical affiliation, integration of production processes, relationship between enterprises, and benefits for the enterprises in the cluster. These approaches to assessing cluster effectiveness can be divided into the following groups: methods based on measuring individual effects, methods based on cluster assessment through investment projects, parametric methods, and methods based on assessing cluster competitiveness. Most available methods and techniques for assessing cluster effectiveness are related to industrial clusters and are therefore not applicable to digital clusters.

Based on the results obtained, it is possible to assess a cluster's capacity for innovative activities in the field of digital products and the prospects for achieving the main strategic goal of the cluster. The authors proposed a method that classifies administrative districts by their stage of digital development. This is a starting point for the digitalization strategy in the region, as it enables researchers to achieve regional projects' targets in the field of digital economy.

\section{Acknowledgements}

This research was supported by the Academic Excellence Project 5-100 proposed by Peter the Great St. Petersburg Polytechnic University.

\section{References}

Abashkin, V., Artemov, S., Gusev, A., Khafizov, R., Kutsenko, E., Zaurova, E., 2018. Cluster Policy in Russia: From Local Advantages to Global Competitiveness. Ministry of Economic Development of the Russian Federation; RVC JSC; National Research University Higher School of Economics. - Moscow: HSE, 2018, pp. 1-88

Andreyeva, D.A., Irina, I.V.K., Dvas, G.V., Malinin, A.M., Nadezhina, O.S., 2018. Factors of Effective Regional Development and Labor Market Condition as Indicator of State of the Economy of the Region. In: Proceedings of the $31^{\text {st }}$ International Business Information Management Association Conference, 25-26 April 2018, Milan, Italy, IBIMA publishing, pp. 5507-5513 
Beloglazova, S.A., 2019. Кластерная форма организации экономики: определение потенциала и направлений развития в регионах России (Cluster Form of Economic Organization: Determining the Potential and Directions of Development in the Regions of Russia). PhD Thesis, Volgograd State University, pp. 268

Berawi, M.A., 2018. Managing Sustainable Infrastructure and Urban Development: Shaping a Better Future for ASEAN. International Journal of Technology, Volume 9(7), pp. 12951298

Berawi, M.A., Suwartha, N., Fathiya Salsabila., Gunawan., Perdana Miraj., Woodhead, R., 2019. Land Value Capture Modeling in Commercial and Office Areas using a Big Data Approach. International Journal of Technology, Volume 10(6), pp. 1150-1156

Boekholt, P., Thuriaux, B., 1999. Public Policies to Facilitate Clusters: Background, Rationale and Policy Practices in International Perspective. In: Boosting Innovation: The Cluster Approach, OECD, pp. 381-412

Caragliu, A., de Dominicis, L., De Groot, H.L.F., 2016. Both Marshall and Jacobs Were Right!. Journal of Economic Geography, Volume 92(1), pp. 87-111

Chen, X., Wang, E., Miao, C., Ji, L., Pan, S., 2020a. Industrial Clusters as Drivers of Sustainable Regional Economic Development? An Analysis of an Automotive Cluster from the Perspective of Firms' Role. Sustainability, Volume 12(7), pp. 1-22

Chen, P., Xie, R., Lu, M., 2020b. "Resource Conservation" or "Environmental Friendliness": How do Urban Clusters Affect Total-Factor Ecological Performance in China? International Journal of Environmental Research and Public Health, Volume 17(12), pp. 1-28

Delgado, M., Porter, M.E., Stern, S., 2015. Defining Clusters of Related Industries. Journal of Economic Geography, Volume 16(1), pp. 1-38

Fracasso, A., Vittucci Marzetti, G., 2018. Estimating Dynamic Localization Economies: The Inadvertent Success of the Specialization Index and the Location Quotient. Regional Studies, Volume 52(1), pp. 119-132

Government of the Russian Federation, 2014. Государственная программа «Экономическое развитие и инновационная экономика» (State Program of the Russian Federation «Economic Development and Innovative Economy»)

Government of the Russian Federation, 2017. Программа «Цифровая экономика Российской Федерации» (Program «Digital Economy of Russian Federation»).

Gutman, S.S., Zaychenko, I.M., Kalinina, O.V., 2017. Selection of Strategy Implementation Tool for Shipbuilding Cluster of Arkhangelsk Oblast. In: Proceedings of the 29th International Business Information Management Association Conference, 3-4 May 2017, Vienna, Austria, IBIMA publishing, pp. 1430-1438

Humphrey, J., Schmitz, H., 2002. How Does Insertion in Global Value Chains Affect Upgrading in Industrial Clusters? Regional Studies, Volume 36(9), pp. 1017-1027

Ibragimova, R.S., Tokunov, A.A., 2016. Evaluation of the Effectiveness of Textile Clusters: A Methodological Aspect. Modern High Technology, Regional Application, Volume 3(47), pp. 75-84

Isaksen, A., 2018. From Success to Failure, the Disappearance of Clusters: A Study of a Norwegian Boat-building Cluster. Cambridge Journal of Regions, Economy and Society, Volume 11(2), pp. 241-255

Kleiner, G.B., Kachalov, R.M., Breast, N.B., 2008. Синтез стратегии кластера на основе системноинтеграционной теории (Synthesis of Cluster Strategy Based on Systemintegration Theory. Management of Science and Scientometrics). Industrial Markets, 66(18), pp. 9-39 
Kovaleva, T.Y., 2018. Theoretical-methodological Bases and Results of Estimation of the Effectiveness of Cluster Spatial Development of the Russian Federation Regions. Vestnik of Astrakhan State Technical University. Series: Economics, Volume 2018(2), pp. 101-111

Kozonogova, E., Elokhova, I., Dubrovskaya, J., Goncharova, N., 2019. Does State Cluster Policy Really Promote Regional Development? The Case of Russia. In: IOP Conference Series: Materials Science and Engineering, Volume 497(1), pp. 12044

Kudryavtseva, T., Rodionov, D.G., Skhvediani, A.E., 2018. An Empirical Study of Information Technology Clusters and Regional Economic Growth in Russia. In: SHS Web of Conferences, Volume 44, pp. 1-11

Kudryavtseva, T., Skhvediani, A., Ali, M. 2020. Modeling Cluster Development using Programming Methods: Case of Russian Arctic Regions. Entrepreneurship and Sustainability Issues, Volume 8(1), pp. 150-176

Kuporov, Y.Y., Avduevskaya, E.A., Bogacheva, T.V., 2018. Investments in Human Capital: Efficiency of investments in higher education in Russia. In: Proceedings of the $31^{\text {st }}$ International Business Information Management Association Conference, IBIMA 2018: Innovation Management and Education Excellence through Vision 2020, 25-26 April 2018, Milan, Italy, pp. 926-940

Lehmann, E.E., Menter, M., 2018. Public Cluster Policy and Neighboring Regions: Beggarthy-neighbor? Economics of Innovation and New Technology. Economics of Innovation and New Technology, Volume 5-6(27), pp. 420-437

Litzel, N., 2017. Does Embeddedness in Clusters Enhance Firm Survival and Growth? An Establishment-level Analysis using CORIS Data. Regional Studies, Volume 4(51), pp. 563-574

Maggioni, M., 2004. The Rise and Fall of Industrial Clusters: Technology and the Life Cycle of Regions. IEB Working Paper 2004/06, pp. 1 -39

Marshall, A., 1890. Principles of Economics. $8^{\text {th }}$ ed. Published in 1920. Palgrave Macmillan, London.

Ministry of Economic Development, 2008. Методические рекомендации по реализации кластерной политики в субъектах Российской Федерации (Methodical recommendations on realization of cluster policy in the Russian Federation).

Moeis, A.O., Desriani, F., Destyanto, A.R., Zagloel, T.Y., Hidayatno, A., Sutrisno, A., 2020. Sustainability Assessment of the Tanjung Priok Port Cluster. International Journal of Technology, Volume 11(2), pp. 353-363

Porter, M.E., 1998. Clusters and Competition: New Agendas for Companies, Governments, and Institutions. Boston, MA, USA: Harvard Business School,

Pososhkov, P., 2017. Кластеризация нефтегазовой отрасли как фактор повышения уровня экономической безопасности России (Clustering of the oil and gas industry as a factor in increasing the level of economic security of Russia. Saint Petersburg), PhD Thesis, Saint Petersburg State University of Economics, pp. 173

Putri, E.P., Chetchotsak, D., Ruangchoenghum, P., Jani, M.A., Hastijanti, R., 2016. Performance Evaluation of Large and Medium Scale Manufacturing Industry Clusters in East Java Province, Indonesia. International Journal of Technology, Volume 7(7), pp. 1269-1279

Rodionov, D., Rudskaia, I., 2019. Problems of Infrastructural Development of "Industry 4.0" in Russia on Sibur Experience. In: Proceedings of the 32 nd International Business Information Management Association Conference, 15-16 November, 2018, Seville, Spain, IBIMA publishing, pp. 3534-3544 
Rudskaya, I., Rodionov, D., 2017. Econometric Modelling as a Tool for Evaluating the Performance of Regional Innovation Systems (with Regions of the Russian Federation as the Example). Academy of Strategic Management Journal, Volume 2(16), pp. 18

Schepinin, V., Skhvediani, A., Kudryavtseva, T., 2018. An Empirical Study of the Production Technology Cluster and Regional Economic Growth in Russia. In: Amorim, M.P.C., Costa, C., Au-Yong-Oliveira, M., (eds.). Proceedings of the European Conference on Innovation and Entrepreneurship. ECIE 2018, Aveiro, 20-21 September 2018. Academic Conferences and Publishing International Limited: pp. 732-740

Selentyeva, T.N., Degtereva, V.A., Ivanova, M.V., Mikheyenko, O.V., 2018. The Competitiveness of Innovation Clusters: Approaches to Assessing and Role of State Cluster Policy. In: Proceedings of the $32^{\text {nd }}$ International Business Information Management Association Conference, 15-16 November, 2018, Seville, Spain, IBIMA publishing, pp. 1706-1709

Steinfield, C., Scupola, A., López-Nicolás, C., 2010. Social Capital, ICT Use and Company Performance: Findings from the Medicon Valley Biotech Cluster. Technological Forecasting and Social Change, Volume 77(7), pp. 1156-1166

Strøjer Madsen, E., Smith, V., Dilling-Hansen, M., 2003. Industrial Clusters, Firm Location and Productivity - Some Empirical Evidence for Danish Firms. Working Papers 03-26, University of Aarhus, Aarhus School of Business, Department of Economics. Handle: RePEc:hhs:aareco:2003_026

Taglioni, D., Winkler, D., 2016. Making Global Value Chains Work for Development. Trade and Development. Washington, DC: World Bank

Tsertseil, Y.S., Kokuyeva, V.V., 2018. Особенности оценки эффективности промышленных инновационных кластеров в зарубежной литературе (Features of an Estimation of Efficiency of Industrial Innovative Clusters in the Foreign Literature). Economics and Management: Science to Practice Journal, Volume 5(143), pp. 117-121

Wiratmadja, I.I., Govindaraju, R., Handayani, D., 2016. Innovation and Productivity in Indonesian IT Clusters: The Influence of External Economies and Joint Action. International Journal of Technology, Volume 7(6), pp. 1097-1106

Zhu, H., Dai, Z., Jiang, Z., 2017. Industrial Agglomeration Externalities, City Size, and Regional Economic Development: Empirical Research Based on Dynamic Panel Data of 283 Cities and GMM Method. Chinese Geographical Science, Volume 27(3), pp. 456-470 